\title{
The Impact of Legislative Changes in the Tobacco Industry on South Africans - Clearing the Air
}

\section{Leon de W Fourie}

Department of Public Management, Technikon Pretoria

\section{Johan de Jager}

Department of Marketing, Technikon Pretoria

\section{ABSTRACT}

The purpose of this article is to gain insight in the South African tobacco industry, its influence on the community and the role of anti-tobacco campaigns. This is done by conducting an empirical investigation of the attitudes and behaviour of smokers and non-smokers regarding the national government campaigns against tobacco products. Consequently, it will contribute in determining the efficiency of the anti-tobacco campaigns as well as the effect of the Tobacco Products Control Amendment Act, 1999 (Act 12 of 1999) on smokers and non-smokers. It is postulated that by applying the principles of marketing (demarketing and remarketing) it could contribute significantly in influencing smoking behaviour amongst South Africans.

JEL K2, D12

\section{INTRODUCTION}

An international survey conducted by Medline in 2001, concluded that tobacco usage not only has a negative affect on the health of those who do smoke, but secondary smoke is also harmful to non-smokers. Passive smoking is widespread, and environmental tobacco smoke contains many potent respiratory irritants. Data collected from 7882 adults (age 20-48 years) who had never smoked, from 36 centres in 16 countries researched the effect of passive smoking on respiratory symptoms, bronchial responsiveness, and lung function of non-smokers. The study concluded that more than 50 percent of participants showed signs of respiratory diseases from passive smoking. It could be argued that decreasing involuntary exposure to tobacco smoke in the community, especially in workplaces, is likely to improve respiratory health (Riley et al., 2000: 1). 
It is common knowledge that tobacco usage is one of the chief preventable causes of death in the world. The World Health Organisation (WHO) attributes some 4 million deaths per year to smoking. This figure is expected to rise to 8.4 million deaths per year by 2020 (Riley et al., 2000: 1). In another study, Bechoo (2001: 1) similarly concluded that by the year 2020 tobacco related deaths are expected to rise to 10 million a year. Disconcertingly, it is determined that 70 percent of these deaths will be in developing countries, which does not bode well for South Africa. The Human Sciences Research Council (HSRC) and Medical Research Council (MRC) in November 1998 estimated that more than 4 million people worldwide die of tobacco related illnesses every year. In South Africa alone an estimated 25000 people die of diseases attributed to cigarette smoking every year. Smokers lose an average of 12 years of life expectancy due to the smoking habit. The research statistics conducted by the HSRC and MRC show the following estimated prevalence among South African adults: 41 percent African males; 3 percent African females; 62 percent Coloured males; 41 percent Coloured females; 47 Indian males; 1 percent Indian females; 45 percent White males and 28 percent White females. This brings the number of smokers in South Africa to almost 25 percent of the population (Riley et al., 2000: 1).

Contrary to popular belief and extensive anti-smoking campaigns by the national government, smoking is on the increase among young people. As a result the South African national government and other stakeholders, such as churches and schools, have called for concerted action against tobacco use in public places, the workplace and smoking by especially young people (Riley et al., 2000: 1). In terms of section 24 of the Constitution of the Republic of South Africa, 1996 (Act 108 of 1996) every South African has the right to an environment "...that is not harmful to their health or well-being". This has led to the Tobacco Products Control Amendment Act, 1999 (Act 12 of 1999), prohibiting the advertising and promotion of tobacco products; prohibiting the free distribution of tobacco products; limiting smoking in public places including the workplace and; allowing for the regulation of the nicotine and tar levels of tobacco.

According to Kotler \& Levy (1969: 10-15) marketing principles are not only applicable to profit organisations, but are also used by non-profit organisations in order to obtain their objectives. These marketing principles are not only applicable on goods and services, but can be extended to be applied to organisations, places and ideas. Idea marketing is better known as social marketing because it deals with the marketing of social affairs. This includes aspects such as road safety campaigns, family planning and anti-tobacco campaigns. 
The purpose of this paper is to gain insight in the tobacco industry, its influence on the community and the role of anti-tobacco campaigns. This is done through conducting an empirical investigation of the attitudes and perceptions of smokers and non-smokers regarding the national government campaigns against tobacco products. Consequently, it will contribute in determining the efficiency of the anti-tobacco campaigns as well as the effect of the Tobacco Products Control Amendment Act, 1999 (Act 12 of 1999) on smokers and non-smokers. It is postulated that by applying the principles of marketing it could contribute significantly in influencing smoking behaviour amongst South Africans.

\section{RESEARCH OBJECTIVES}

Tobacco smoking is an addictive habit. People who are addicted have great difficulty in giving up tobacco smoke and the smoking cessation strategies have at best an approximately 20 percent success rate. Thus, it is important to ensure that South Africans are not exposed to marketing forces that promote smoking behaviour. With this borne in mind the objectives of this research are to investigate the:

- perceived success of anti-tobacco groups in limiting smoking;

- extent of the tobacco industry's involvement in smoking;

- influence of restrictive measures on tobacco products in South Africa;

- influence of the Tobacco Products Control Amendment Act, 1999 (Act 12 of 1999) on various stakeholders;

- counteractions by the tobacco industry as a result of the Tobacco Products Control Amendment Act, 1999 (Act 12 of 1999); and

- success of anti-tobacco campaigns as perceived by inhabitants in the greater Pretoria region conducted by means of an empirical survey.

\section{METHOD OF THE STUDY}

An ontological approach to the study allows the researchers to study the reality of the impact of Tobacco Products Control Amendment Act, 1999 (Act 12 of 1999) on smokers and non-smokers. The research topic lends itself to utilising predominantly a historical and descriptive research technique. Historical research will enable the researchers to give rational explanation and reasons why the incidence of tobacco related diseases are inordinately high in South Africa. Descriptive research will assist the researchers to look beyond mere factual information, by using observation as a means of obtaining information regarding smokers' behaviour and non-smokers' reaction to substantiate arguments. 
An ontological approach implies that the researchers will mainly focus on secondary data. In this case secondary data pertains to data that was collected by other researchers concerning the tobacco industry. Secondary data is used to get insight on the tobacco industry, its influence on the community and the success of anti-tobacco campaigns. Primary data was collected from the attitudes and perceptions of smokers and non-smokers regarding the use of tobacco products, as well as tobacco legislation. This was done to determine the efficiency of the anti-tobacco campaigns as well as the effect of the Tobacco Products Control Amendment Act, 1999 (Act 12 of 1999) on smokers and nonsmokers. This further implies that the research theme was approached from a both quantitative and qualitative research perspective. Quantitative research data was obtained by means of the empirical survey conducted in the Pretoriaregion; whilst qualitative research data was obtained through the perceived behaviour of smokers leading to discovering novel or unanticipated findings.

Seven hundred households were selected at random in Pretoria, Centurion, Akasia and Mamelodi. These households were issued with two different structured questionnaires, which had to be completed by the head of the household. The stratified sample method was used to ensure that the correct ratio of questionnaires was distributed in each sub-unit. Following this procedure, the systematic sample method was used to select the desired sample unit. Initially the head of the household was approached to participate to the survey. In the event that the head of the household was unavailable or unable to assist, a substitute of the age of 18 years or older was selected.

Chi square tests of dependency were used to test relationships on a 5 per cent level of significance. Dependencies were tested between the outcomes of the two different studies related to selected smoking related questions. These are appropriately highlighted in the article.

\section{HEALTH HAZARDS OF TOBACCO SMOKE}

Environmental Tobacco Smoke (ETS), also known as second-hand smoke, is the smoke given off by the burning tip of a cigarette, cigar, or pipe, and the smoke exhaled by the person who is smoking it. The smoke of tobacco products contain over 4000 chemical compounds, more than 43 of them can cause cancer in humans. In a working life of 40 or more years, exposure to tobacco smoke at work can be considerable. It is a scientific fact that passive smoking causes lung cancer and heart disease in non-smokers. The World Health Organisation (WHO) estimates that nearly 700 million, or almost half the world's children, breathe air polluted by tobacco smoke, particularly at home. Children and infants exposed to second hand smoke are vulnerable to diseases such as Sudden 
Infants Death Syndrome (SIDS), higher risk of pneumonia and bronchitis, higher risk of developing asthma and worsened asthma.

According to the Tobacco Action Group (TAG), the National Cancer Association, the Heart Foundation of South Africa and the Council Against Smoking, (www. cansa.org.za) tobacco smoke has the following inherent health hazards:

- Smoking robs a person from energy giving oxygen and replaces it with up to 15 percent carbon monoxide. Carbon monoxide is a poisonous chemical and causes amongst other reduced stamina in smokers.

- Smoking causes the heart to work harder and increases the chance of heart deceases.

- Nine out of ten smokers present evidence of emphysema, a dismantling disease that causes a painful and slow death. Emphysema destroys the air bags in the lungs causing difficulty to breath.

- Tobacco is responsible for one out of every three cancer mortalities. Tobacco smoke does not only cause lung cancer, but is also responsible for other cancers such as mouth, kidney, bladder and cancer of the pancreas.

- Passive smoking causes cancer amongst non-smokers. Inhaling of second hand smoke increases the risk on heart attacks by 30 percent. In the United States of America 53000 people die annually due to passive smoking (Alberts, 1993: 10). In China, this figure is an alarming 500000 people per annum (Anon, 1996: 932).

- The Medical Research Council of South Africa determined that almost one third of South Africans die as a direct result of smoking.

Taking the abovementioned into consideration it is clear that action groups against the use of tobacco products have significant factual foundations to substantiate their arguments and launch their campaigns. The application of social marketing principles is thus undoubtedly a useful tool in the campaign against smoking.

\section{ACKNOWLEDGING TOBACCO SMOKE AS A HEALTH HAZARD}

Health hazards caused by smoking have not been high on the international health agenda. Concern over the health hazards caused by cigarette smoke had gained some attention in the 1950s in the United States of America. However, it was only after the Surgeon General's report in 1964 that public policymakers in 
the United States of America began to launch considerable efforts to alter the American public's smoking behaviour. In 1967 the Department of Health and Human Services (DHHS) spent more than 20 million rand in an effort to inform consumers of the health hazards of smoking. DHHS used tactics as bumper stickers that read "Smoke, Choke, Croak" and endorsements from athletic stars such as Peggy Flemming and Bart Starr claiming: "I don't smoke". In general, the approach was to depict smokers as distraught coughers, whereas nonsmokers were portrayed as happy and healthy. These promotional efforts had some limited impact on smoking behaviour. It was discovered that cigarette sales fell by 1.3 billion cigarettes annually and that the number of American smokers dropped by a total of 71.5 million to 70 million smokers. However, it was found that rather than a steady decline in cigarette sales or the number of smokers, the major behavioural trend has been toward the purchase of low-tar and low nicotine brands (Mowen, 1996: 833). It can therefore be deducted that the American government's attempts to change smoking behaviour among its citizens was to an extent successful.

During the 1990s the negative publicity concerning smoking and the actions of the tobacco industry escalated. In 1994 a national poll was conducted which found that 68 percent of all Americans believed that cigarette advertisements influence children and teenagers to smoke. The results also revealed that two thirds of Americans, including half of all the smokers, wanted the government to place greater restrictions on cigarette advertising. More than 50 percent of those polled wanted all cigarette advertising banned (Mowen, 1996: 833). A survey conducted in 1998 by the Xinhua News Agency in South Africa, similarly indicated that 70 percent of smokers and 90 percent of non-smokers favoured a ban on smoking in public and the workplace. (Xinhua News Agency, 2000: 15 and White, 2001: 1).

To illustrate the extent of tobacco promotion budgets, De Jager (1997: 3) reported that the promotion budget for cigarette companies in England in 1996, amounted to 100 million pounds (143 million US dollars), while anti-tobacco campaigns amounted to 150000 pounds (215 217 US dollars). Thus, in monetary terms a clear indication that anti-tobacco campaigns have a lesser impact on smokers than promotions and advertisements offered by the tobacco industry.

White (2001: 1) claims that prior to the end of apartheid in 1994, a third of all South Africans smoked, excise taxes were low and there were few tobacco control measures. According to the Human Sciences Research Council (HSRC) 52 percent of the males in South Africa are smokers, placing South African male smokers sixteenth in the world. 


\section{LEGISLATIVE MEASURES TO CONTROL THE TOBACCO INDUSTRY}

On 14 August 1998, Dr. Gonda Perez, of the Department of Health announced that: "Government has a responsibility to protect our young people from the dangers of smoking. While we can utilise health warnings on packaging and advertisements to inform the public of the dangers of tobacco, it is not enough. Warnings are directed at smokers to encourage them to quit and young people, starting to smoke tend to ignore the health warnings. We therefore need to act against advertising which encourages young people to see smoking as symbol of independence, a way to boost self esteem and self confidence."

The South African government embarked on a plan to discourage people's smoking habits, especially males (White, 2001: 1). The end of apartheid and democratisation of South African in 1994, was an important step in the government's shift away from support for the tobacco industry. In the period 1996 to 1998 the South African tobacco industry spent approximately 240 million rand (20.8 million US dollars) a year on advertising and promotions. The tobacco industry claimed that it did not influence anyone to smoke, but were merely competing for market share. (Zuma, 1998: 1). The tobacco industry objected to proposed amendments to the Tobacco Products Control Act, 1993 (Act 83 of 1993), by challenging the then Minister of Health, Dr. Nkosazana Zuma, in court. Despite their plea that the proposed amendments would lead to 15000 people becoming unemployed, the tobacco industry lost the court case.

Despite an American ban on television commercials promoting tobacco products, the tobacco industry continues to survive. It could be argued that poor communication strategies by anti-smoking groups were in part to blame, but the root causes are the strong social reward for smoking in some circles (Mowen, 1996: 833). The limited success achieved through government regulation is therefore not unique to South Africa - a five year experiment with an outright ban on cigarette advertising in Canada, saw an operating profit of more than double because of the huge cutback in advertising costs Greising (2001: 49).

The Tobacco Action Group (TAG), a coalition consisting of the National Council Against Smoking, the Cancer Association of South Africa, and the Heart Foundation of South Africa, helped raise public awareness about smoking hazards and drove tobacco control to the forefront of the political agenda. As a result, precautions have been in place since 1993 to control the use of tobacco products in public. In terms of section 83 of the Tobacco Products Control Act, 1993 (Act 12 of 1993), the Minister of Health is authorised to promulgate regulations to prohibit smoking in official places. This led to the 
implementation of the Tobacco Products Control Amendment Act, 1999 (Act 12 of 1999) prohibiting the advertising and promotion of tobacco products; prohibiting the free distribution of tobacco products; limiting smoking in public places including the workplace and; allowing for the regulation of the nicotine and tar levels of tobacco. In 1994 the act was strengthened, requiring stronger health warnings and restricting smoking in government buildings and in certain types of private businesses (White, 2001: 1).

In terms of section 7 of the Tobacco Products Control Amendment Act, 1999 (Act 12 of 1999), a person caught smoking in a non-smoking area will be fined up to R200, while companies which contravenes the regulations face fines up to R200 000. Children under the age of 16, in terms of section 5, are not allowed to purchase tobacco products and retailers can be fined should they be found selling tobacco products to children. The bottom line is that a smoke-free environment will limit the number of tobacco related illnesses that from which the population suffers.

The Tobacco Products Control Amendment Act, 1999 (Act 12 of 1999), also stipulates that public places should have smoking and non-smoking areas, and that not more than 25 percent of public places including the workplace, restaurant, pub, shebeen or bar should be allocated for smoking. A concrete wall or solid partition should divide the smoking area form the non-smoking area. The smoking area should have ventilation in a form of a window or an electronic ventilation. If the floor space takes only 32 people no smoking is allowed at all.

Soolojee quoted in White (2001: 11) denied insinuations that the government is hesitant to place a total ban on smoking, due to a loss of potential income. An outright ban on smoking would result in criminalising smoking and cause them to move underground. However, according to Kotler and Andreasen (1996: 450), governments are not inclined to place a general embargo on the use of tobacco products. This is due to the fact that government's, as in the case of South Africa, are dependent on the revenue, which results from the tobacco industry.

\section{IMPACT OF LEGISLATIVE MEASURES ON STAKEHOLDERS}

The tobacco industry argued that tobacco is vital to the South African economy because it creates jobs and is an important farm crop. However, despite greatly increased consumption of tobacco in South Africa, since 1950 the number of tobacco farms and the amount of land cultivated has both steadily declined. The University of Cape's Project on the Economics of Tobacco Control studied the 
employment in the tobacco-manufacturing sector in South Africa between 1945 and 1995. The studies showed that there was a considerable decrease in employment over the stated period, or an estimated 5.6 percent per year.

The Tobacco Products Control Amendment Act, 1999 (Act 12 of 1999) has had an impact on a number of stakeholders. It could be argued that the act negatively impacted on the freedom of speech as stipulated in section 16 of the Constitution of the Republic of South Africa, 1996 (Act 108 of 1996). Consequently the proposed prohibition of tobacco advertisements made the act a controversial issue in the press and media. On the one hand the use of tobacco products is acceptable; but on the other hand the smoker's right to be informed is negated.

The Tobacco Products Control Amendment Act, 1999 (Act 12 of 1999) has had far reaching consequences for the media. The prohibition of traditional tobacco promotions causes considerate damage to the press. According Van Deventer, Executive Head of Nasionale Koerante, this led to poor service rendering to news agency customers because of the consequent reduction in advertisement income as a result of the prohibition imposed by the act (De Jager, 1997: 5). Jurgens (1997: 12) is of the opinion that the "...tobacco industry is unlawfully harmed because of all the constraints imposed on the sales of tobacco products". Although excise duty and corporative tax is paid to government, the Department of Health does not show much interest in negotiations with the tobacco industry. Du Plessis (2001: 3) confirms that the tobacco industry endeavours to have a constructive relationship with government regarding this issue, but that antitobacco organisations attempt to create a gap between the tobacco industry and the government. In response the tobacco industry make the usual noises when faced with increased regulations, primarily that the laws are too strict and would carry a high economic cost. It is also alleged that the tobacco industry claims that the legislation would harm the tourism industry, and even lobbied the Minister of Tourism for support.

According to White (2001: 1) various pressure groups such as the Freedom of Commercial Speech Trust, representing the media and marketing industries; the South African Chamber of Business; the American Chamber of Business and the Council of South Africa Banks; lobbied against the proposed advertising bans. Furthermore, stakeholders such as the Food and Allied Workers Union (representing the tobacco manufacturing workers), international experts and sports and cultural recipients of tobacco sponsorships, were influenced by the tobacco industry to testify against the proposed act. According to White (2001: 4 ), however, the tobacco industry publicly claimed that although the opportunity for smoking became less they did not expect a drop in tobacco sales. 
The Tobacco Products Control Amendment Act, 1999 (Act 12 of 1999) also had a negative impact on job creation opportunities and economic activity in the tobacco industry, the media, the advertising industry, and the government as well as tobacco action groups.

South African soccer lost 10 million rand in revenue in tobacco sponsorship annually with the scrapping of the Rothmans Cup due to the government's anti smoking legislation. The result was that the South African Football Association (SAFA) had to find new sponsorship. SAFA, however, joined the anti-smoking lobbyist promoting a healthy lifestyle amongst its players and the public (Naidoo, 2001: 1).

The most significant question was to determine if the Tobacco Products Control Amendment Act, 1999 (Act 12 of 1999) had the desired effect on the smoking behaviour of South African citizens. The government anticipated that a ban on tobacco advertising would effectively reduce the number of smokers, either aspirant or existing. Palmer (1998: 4) points out that statistics from European countries where curbs have been placed on tobacco advertising for sometime, actually showed an increase in tobacco consumption. Although in Norway, Finland, New Zealand and France bans on tobacco advertising and promotions resulted in a decrease of between 14 and 37 percent in cigarette sales since the ban in 1996. It could be argued that it is difficult to determine what the impact of tobacco legislation would have on citizens, because it could result in both a decrease or increase in smoking behaviour.

\section{NOVEL TOBACCO MARKETING PLOYS}

It is clear that the Tobacco Products Control Amendment Act, 1999 (Act 12 of 1999) had a significant impact on the marketing strategy of the tobacco industry. In 1998 the tobacco industry spent approximately a quarter of a billion rand (21 739 billion US dollars) on publicity and promotion. The perceived fear that a prohibition on advertisements and promotions would lead to a decrease in tobacco sales figures was eminent. Interestingly, tobacco companies halted their advertisements three months before they were obliged by law to do so (Keenan, 2001: 11). Whether it was done in good faith of the government's anti-smoking campaign or just a clever marketing ploy by the tobacco industry is difficult to determine. It could be argued that this was the inception phase of nontraditional, creative advertising of tobacco products.

The tobacco companies had to devise novel ways of reaching its market. The predominant question was how to reach a market that by law could not see nor hear tobacco advertisements, or a market that could not be targeted by means of 
promotions? White (2001: 4) is of the opinion that in the past the tobacco industry circumvented laws, exploiting loopholes in the law and often disregarded it altogether. Bednall quoted in Keenan (2001: 11) concurs that it is possible, through mass events such as concerts or utilising the internet, web pages and cellular phones, to reach a particular market. This approach is permissible with the proviso that permission has been obtained. However, it remains a fact that tobacco companies can no longer influence non-smokers directly.

Bednall quoted in Keenan (2001: 11) points out that unique cellular phone messages have been developed which could add value to smokers by informing them about aspects that are perceived to be of personal interest for the smokers. In doing so, the smokers' interests are determined, and it becomes possible for the tobacco companies to focus their marketing strategies on those interests. In other words a client relationship is created. Keenan (2001: 11) aptly states that “...cellular phones are the new road to a person's lungs because cigarette companies are concentrating on lower income groups and Third World Countries, the same market on which cellular sales are aimed". Greising (1996: 49) agrees with this new creative personal method and argues that the tobacco companies are continuously looking for novel methods to comply with changing legislation. The cellular approach seems promising for the interim, but government and anti-smoking agencies continuously try and foil such manoeuvres.

Palmer (1998: 4) supports a non-traditional approach to marketing the tobacco industry and proposes alternative ways of promoting tobacco products. Nontraditional techniques circumvent the prohibitions in terms of Tobacco Products Control Amendment Act, 1999 (Act 12 of 1999). Techniques for example, include advertising on the internet, the motion picture industry, and even direct approaches such as direct mail. These techniques cannot be inhibited because of the right to free speech in terms of section 16 of the Constitution of the Republic of South Africa, 1996 (Act 108 of 1996).

Palmer (1998: 4) argues that the only effective way to curb the smoking habit, is to educate the public. This argument is supported by Mason (2001: 1) who points out that there are better ways of curtailing the smoking habit. In this regard he propagates improved scholastic education and the promotion of a healthier life-style through advertising. According to Twinn (2001: 1) health warnings are not effective, and a product such as tobacco, even becomes more alluring when a warning is attached to it.

According to Kotler and Clark (1985: 16) demarketing, or otherwise referred to as unselling campaigns, seeks to reduce the overall demand of a product and 
implies such actions as raising prices, and/or reducing promotion, access, or service. In other words, demarketing requires finding ways to discourage demand of a product temporarily or permanently. Products considered unwholesome, such as tobacco, alcohol, and drugs, will attract organized efforts to discourage their consumption. The marketing task is to get consumers to quit, or at the very least reduce the use of a harmful product (Mowen, 1995: 290291). Anti product marketers use the same tools as demarketers, although the former are also more likely to use promotional communication and reduced availability to discourage consumption. In this context demarketing schemes against tobacco usage are aimed at countering the marketing efforts of tobacco companies.

Demarketing of tobacco products by the South African government would, for example imply a legislative prerequisite for the placement of warning labels on tobacco products. The goal of the warning labels is to influence attitudes by identifying an attribute that results in a negative outcome, for example "Smoking causes cancer" or "Smoking is harmful to children" and "Smoking is hazardous to your health". An interesting strategy by the South African government to complement their demarketing approach is to place radical tax increases on tobacco products from year to year, otherwise known as "sin tax".

Scott (1995: 1) claims that instead of discouraging smoking through demarketing, a remarketing approach should be followed. This implies that instead of deliberately making tobacco use less attractive, another option should be made more attractive, for example promoting a healthier life-style through national health weeks or using opinion formers such as prominent sport personalities. The challenge is to redirect marketing efforts towards discovering, developing, and delivering options that satisfy both tobacco companies and consumers.

While legislation and regulatory policies are in place to control the extensive use of tobacco products and the exposure of non smokers to hazardous conditions, demarketing efforts by both the government and non profit organisations may be implemented in addition to discourage the demand for tobacco products. While demarketing efforts in areas such as health care may be questionable and even regarded as unethical, demarketing efforts can be implemented without any doubt in an attempt to control smoking behaviour.

Marketing is about giving customers a choice. While it is the duty of the government to legislate the use of tobacco products, and it was seen earlier that banning measures might in fact increase consumption, it is suggested that nonprofit attempts such as anti-tobacco campaigns should engage in positive options 
to discourage the use of tobacco products. It should offer and deliver better ways to meet the basic consumers needs that drive demand for unhealthy habits.

Against this background the research findings of the survey conducted in the Pretoria-region, will be discussed.

\section{RESEARCH FINDINGS}

The survey was conducted in January 2002 to determine the attitudes and perceptions of the public in the Pretoria-region regarding tobacco smoke. The results of the survey were compared with a similar survey conducted by the researchers in 1997.

Of the seven hundred households that were surveyed, 55 percent of the respondents were males and 45 percent were females. The majority of the respondents (62 percent) were either Xhosa, Zulu or Sotho speaking; whilst 12 percent were Afrikaans speaking, 16 percent English speaking; and 10 percent indicated that they speak a foreign language. Notably 66 percent of the respondents indicated that they were in the age category between 16 and 24 years of age. Fifty one percent of the respondents have indicated that they were non-smokers, whilst 49 percent were smokers.

Table 1 Smoker/non smoker

\begin{tabular}{||l|c|c|c|c||}
\cline { 2 - 5 } \multicolumn{1}{c|}{} & \multicolumn{2}{c|}{$\mathbf{1 9 9 7}$} & \multicolumn{2}{c||}{$\mathbf{2 0 0 2}$} \\
\hline \hline Smoker & N & Percent & N & Percent \\
\hline Yes & 180 & 46 & 149 & 49 \\
\hline No & $\mathbf{2 1 4}$ & $\mathbf{5 4}$ & $\mathbf{1 5 3}$ & $\mathbf{5 1}$ \\
\hline
\end{tabular}

There was a marginal increase of 3 percent in the number of smokers in the period 1997 to 2002. It would therefore seem that the Tobacco Products Control Amendment Act, 1999 (Act 12 of 1999), did not have the desired outcome of reducing the smoking behaviour of South Africans. Thirty six percent of the respondents regarded themselves as heavy smokers, 31 percent as social smokers and 33 percent as light smokers. 


\section{Table 2 Number of cigarettes smoke per day}

\begin{tabular}{||l|c|c|c|c||}
\cline { 2 - 5 } \multicolumn{1}{c|}{} & \multicolumn{2}{c|}{$\mathbf{1 9 9 7}$} & \multicolumn{2}{c||}{$\mathbf{2 0 0 2}$} \\
\hline \hline Per day & N & Percent & N & Percent \\
\hline $\mathbf{1}-\mathbf{5}$ & 43 & 24 & $\mathbf{6 2}$ & $\mathbf{4 2}$ \\
\hline $\mathbf{6}-\mathbf{1 0}$ & 55 & 31 & 38 & 26 \\
\hline $\mathbf{1 1}-\mathbf{2 0}$ & $\mathbf{5 9}$ & $\mathbf{3 3}$ & 25 & 17 \\
\hline $\mathbf{2 0}$ and more & 23 & 13 & 24 & 16 \\
\hline
\end{tabular}

Chi square dependency test. $\mathrm{p}<0.0001$. There is a significant dependency between the different studies related to the questions.

According to Table 2, sixteen percent of the respondents indicated that they smoke more than twenty cigarettes per day. The table shows an increase of 3 percent of persons smoking more than 20 cigarettes per day compared with the 1997 study. However, it seems as if there was a significant shift towards smoking less cigarettes per day compared with the 1997 study. This could indicate that the prohibitions placed on the tobacco industry have had the desired effect of reducing the numbers of people who start to smoke. On the other hand, it could indicate that the health warnings are taken seriously, and that although people do not stop smoking, they at least smoke less.

\section{Table $3 \quad$ Motive for smoking}

\begin{tabular}{||l|c|c|c|c||}
\cline { 2 - 5 } \multicolumn{1}{c|}{} & \multicolumn{2}{c|}{1997} & \multicolumn{2}{c||}{$\mathbf{2 0 0 2}$} \\
\hline \hline Motive & N & Percent & N & Percent \\
\hline Pleasure & 66 & 37 & $\mathbf{6 2}$ & $\mathbf{4 2}$ \\
\hline & 29 & 16 & 26 & 18 \\
\hline Habit & $\mathbf{7 6}$ & $\mathbf{4 3}$ & 54 & 36 \\
\hline Group pressure & 5 & 3 & 2 & 1 \\
\hline Other & 4 & 2 & 5 & 3 \\
\hline
\end{tabular}

Forty two percent and 36 percent of the respondents have indicated that they are smoking for pleasure or because of habit respectively. The percentage of persons that have indicated that they smoke for pleasure have increased by 5 percent, while the respondents that have indicated that they are smoking because of habit, has decreased by 7 percent. It is significant the percentage of respondents that smoke out of habit has dropped. This indicates that the reinforcement of habit provided through advertisement and promotions could actually contribute to increase smoking behaviour. In other words, the 
restrictions on advertisements and promotions have caused a drop in habitual smoking behaviour. Apart from this, 87 percent of the respondents have indicated that they prefer smoking cigarettes, 7 percent cigars, 2 percent pipe and 4 percent other tobacco products.

Table 4 Influence of compulsory warnings

\begin{tabular}{||l|c|c|c|c||}
\cline { 2 - 5 } \multicolumn{1}{c|}{} & \multicolumn{2}{c|}{1997} & \multicolumn{2}{c||}{$\mathbf{2 0 0 2}$} \\
\hline \hline Influence & $\mathbf{N}$ & Percent & N & Percent \\
\hline Yes & 58 & 32 & 29 & 20 \\
\hline No & $\mathbf{1 2 2}$ & $\mathbf{6 8}$ & $\mathbf{9 9}$ & $\mathbf{6 6}$ \\
\hline Not sure & - & - & 21 & 14 \\
\hline
\end{tabular}

Twenty percent of the respondents have indicated that the compulsory warnings on tobacco products have influenced their smoking habits, while 14 percent have indicated that they are not sure whether it does or not. Although the compulsory warnings have influenced the smoking habits of respondents, it is clear that other strategies would have to be devised to influence smoking behaviour.

Table 5 Attempts to quit smoking

\begin{tabular}{||l|c|c|c|c||}
\cline { 2 - 5 } \multicolumn{1}{c|}{} & \multicolumn{2}{c|}{1997} & \multicolumn{2}{c||}{2002} \\
\hline \hline Quit & N & Percent & N & Percent \\
\hline Yes & $\mathbf{1 1 6}$ & $\mathbf{6 4}$ & $\mathbf{9 7}$ & $\mathbf{6 5}$ \\
\hline No & 64 & 36 & 52 & 35 \\
\hline
\end{tabular}

Sixty five percent of the respondents have indicated that they have tried to quit smoking mainly (77 percent) for health reasons. It seems that the clear majority of respondents acknowledged the health hazards of smoking, but were unable to break the habit. Anti-tobacco campaigns were therefore successful in bringing the health hazard message across. It could be argued that future campaigns should contemplate including effective and proven techniques that smokers could utilise to quit smoking. 


\section{Table 6 Reasons for trying to quit smoking}

\begin{tabular}{||l|c|c|c|c||}
\hline \hline & \multicolumn{2}{|c|}{1997} & \multicolumn{2}{c||}{2002} \\
\hline Reason & N & Percent & N & Percent \\
\hline & $\mathbf{8 0}$ & $\mathbf{6 9}$ & $\mathbf{7 6}$ & $\mathbf{7 6 . 8}$ \\
\hline Economic reasons & 31 & 27 & 11 & 11 \\
\hline Group pressure & 4 & 3 & 7 & 7.1 \\
\hline Influence of legislation & 1 & 1 & 5 & 5.1 \\
\hline
\end{tabular}

Chi square dependency test. $\mathrm{p}<0.0001$. There is a significant dependency between the different studies related to the questions

Although 56 percent of the respondents indicated that the government should legislate the use of tobacco products, 85 percent felt that tobacco companies should be allowed to sponsor sporting events. It seems that the public cannot make the connection between allowing sponsorships or advertisements and how it impacts on the smoking behaviour of citizens. It could be argued that the public needs to be sensitised about the impact that promotions and advertisements have on human behaviour. The survey produced a number of other noteworthy results:

- Fifty four percent of the respondents have indicated that smoking should be prohibited in restaurants, while 50 percent have indicated that it should also be prohibited in public places. Generally proprietors of businesses and managers of work places have complied with the restrictions on smoking in public places.

- Eighty three percent of the respondents have indicated that they adhere to the legislation as to where they are allowed to smoke or not. Seventeen percent have indicated that they are mot bothered with the legislation at all. The restrictions placed on tobacco products are relatively new, and it is understandable that there would be initial rejection of the provisions of the act. The policing of the provisions would in time, lead to a near total compliance of the act.

- Fifty five percent of the smokers have indicated that their parents did not smoke. It could be argued that parental smoking behaviour is not necessarily indicative of children's smoking behaviour. This could indicate that other frames of reference, such as peer group behaviour, dictates smoking behaviour.

- Thirty five percent of the respondents have indicated that they started to smoke at the age of sixteen years of age and younger. It could be argued that the prohibitions of the Tobacco Products Control Amendment Act, 1999 (Act 12 of 1999) relating to advertisements and promotions, would 
lessen the tobacco awareness among children, leading to a decrease in the smoking habit.

Table 7 Main reason for quitting smoking

\begin{tabular}{||l|c|c|c|c||}
\cline { 2 - 5 } \multicolumn{1}{c|}{} & \multicolumn{2}{c|}{$\mathbf{1 9 9 7}$} & \multicolumn{2}{c||}{2002} \\
\hline \hline Reason & N & Percent & N & Percent \\
\hline Health reasons & $\mathbf{6 0}$ & $\mathbf{9 0}$ & $\mathbf{1 8}$ & $\mathbf{4 4}$ \\
\hline Economic reasons & 4 & 6 & 6 & 15 \\
\hline External pressure & 3 & 4 & 3 & 7 \\
\hline Influence of legislation & 0 & 0 & 2 & 5 \\
\hline Other & 0 & 0 & 12 & 29 \\
\hline
\end{tabular}

It is clear from the graph that respondents who indicated that they have smoked, have quitted smoking predominantly because of health reasons. It is interesting that 15 percent indicated that they stopped smoking because of economic reasons. Considering the significant increase in sin taxes in the annual government budget, an average of 9 percent in the period 1999 to 2002, it could be expected that more smokers will kick the habit because of economic reasons.

Table $8 \quad$ Period since stop smoking

\begin{tabular}{||l|c|c|c|c||}
\cline { 2 - 5 } \multicolumn{1}{c|}{} & \multicolumn{2}{c|}{1997} & \multicolumn{2}{c||}{$\mathbf{2 0 0 2}$} \\
\hline \hline Period & $\mathrm{N}$ & Percent & $\mathrm{N}$ & Percent \\
\hline 0 - 6 months & 10 & 14 & $\mathbf{1 3}$ & $\mathbf{3 2}$ \\
\hline 6 months - 1 year & 7 & 9 & 7 & 17 \\
\hline 1 year - 2 years & 12 & 16 & 7 & 17 \\
\hline 2 years - 3 years & 9 & 12 & 3 & 7 \\
\hline 3 years and more & $\mathbf{3 7}$ & $\mathbf{4 9}$ & 11 & 27 \\
\hline
\end{tabular}

The majority of those who have stopped smoking did so only recently. Almost all the respondents who have stopped smoking do not consider smoking again.

Ninety four percent of the respondents admitted that they knew that smoking causes cancer. Almost 70 percent of the respondents felt that smoking is not addictive, whilst 92 percent agreed that smoking could harm those around them. Seventy percent of the respondents have indicated they knew that secondary smoke is more harmful than initial inhalation. Ninety five percent have 
indicated that they understood that smoking could harm a baby during pregnancy. Seventy percent and seventy five percent of the respondents respectively have indicated that it is false that smoking cannot damage a person's lungs or does not cause heart diseases. Fifty five percent were of the opinion that smoking can help to reduce a person's body weight. Almost eighty percent of the respondents have indicated that it is false that smokers generally live longer than non-smokers. Sixty five percent of the respondents have indicated that smokers are generally unhealthy, whilst seventy-five of the respondents felt that smokers in general do not respect non-smokers' right to clear and smoke free air.

\section{CONCLUSION}

Significant amounts of money are spent annually by non-profit organisations such as anti-tobacco campaigns, in an attempt to demonstrate the dangers of tobacco smoke to smokers and potential smokers. South Africa joined the World Health Organisation, World Bank and the growing number of countries, which have taken strong legislative action against tobacco, in response to the global threat to health posed by smoking. In terms of section 3 of the Tobacco Products Control Act, 1993 (Act 83 of 1993) warnings have to be printed on every cigarette packet regarding the dangers of smoking, protecting nonsmokers and the vulnerable such as children, pregnant women and their unborn babies. Health warnings on packaging of all tobacco products available in South African market are compulsory to ensure that people who purchase cigarettes are ware of the dangers of their habit. Legislation was accepted in parliament to restrict advertising and the phasing out of existing sponsorship or contractual agreements with tobacco companies. The success of these actions are not always clear and an attempt should be made to measure the effectiveness of anti smoking campaigns as well as to see whether all these efforts are worth while, thus leading to a reduction in smoking.

Seven hundred households were selected at random in Pretoria, Centurion, Akasia and Mamelodi. These households were issued with two different structured questionnaires, which had to be completed by the head of the household. The results of the survey were compared with a similar survey conducted by the researcher in 1997. The results provided an indication of the extent to which the Tobacco Products Control Amendment Act, 1999 (Act 12 of 1999), was successful in changing smoking behaviour. In this paper it was determined that marketing principles are undoubtedly applicable to governmental programs, such as anti-tobacco campaigns. Insight was gained in the tobacco industry, its influence on the community and the role of anti-tobacco campaigns. An empirical investigation of the attitudes and perceptions of 
smokers and non-smokers regarding the national government campaigns against tobacco products determined the efficiency of the anti-tobacco campaigns as well as the effect of the Tobacco Products Control Amendment Act, 1999 (Act 12 of 1999) on smokers and non-smokers. It was therefore concluded that by applying the principles of marketing it could contribute significantly in influencing smoking behaviour amongst South Africans.

\section{REFERENCES}

1 ANON, (1996) "Aanslag op tabakreklame onregverdige oorregulering". Beeld, August 1.

2 BALETA, A. (1998) "Tough anti-tobacco legislation moves forward in South Africa" The Lancet, November, 14: 1609.

3 BECHOO, I. (2001) "Doctors in bid to end smoking", Daily News, March 27.

4 DE JAGER, J.W. (1997) "Influence of social marketing on the tobacco industry", Paper presented at the EBM conference in Pretoria.

5 GREISING, D. (1996) "Global investing. How cigarette companies aim to beat new laws", Business Week, 70 (11): 44-49.

6 MOWEN, J.C. (1995) Consumer Behaviour (4 ${ }^{\text {th }}$ ed.) Englewood Cliffs: Irwin.

7 NAIDOO, S. (2001) "Safa sees upside of losing R10m sponsorship", www.iol.co.za.

8 KEENAN, T. (2001) "Dis twak dat verbod adverteerders keer", Finansies \& Tegniek, June, 1:11-14.

9 KEENAN, T. (2001) "After government action, tobacco companies' satisfaction", Finance Week, January, 6: 14.

10 KOTLER, P. \& ANDREASEN, A.R. (1996) Strategic Marketing for Non Profit Organizations ( $2^{\text {nd }}$ ed.) Englewood Cliffs: Prentice Hall.

11 KOTLER, P. \& LEVY, J. (1969) "Broadening the concept of marketing", Journal of Marketing: 10-15, January.

12 KOTLER, P. \& CLARK, R.N. (1985) Marketing for Health Care Organizations, Englewood Cliffs: Prentice Hall.

13 MASON, T. (2001) "Alcohol warnings slammed by ISBA", Marketing, December: 13.

14 MOWEN, J.C. (1995) Consumer Behaviour, Englewood Cliffs: Prentice Hall.

15 PALMER, G. (1998) “Today its tobacco ... Tomorrow?", The SA Journal of Marketing and Sales, 4(4): 3-4.

16 RILEY, L., ASMA, S., ERIKSEN, M.P., GREEN, L., BLANTON, C., LOO, C., BATCHELOR, S. \& YACH, D. (2000) "Tobacco use by youth: a surveillance report from the Global Youth Tobacco Survey project", 
Bulletin of the World Health Organisation, July.

17 SCOTT, M. (1995) "Remarketing yes, remarketing health care", Journal of Health Care Marketing, Winter 15(4): 57.

18 SOUTH AFRICA (1999) Tobacco Products Control Amendment Act, 1999 (Act no. 12).

19 TWINN, I. (2001) "Alcohol warnings slammed by ISBA", Marketing, December, 13.

20 WHITE, A. (2001) "The great South African smokeout", Multinational Monitor, 22(1\&2): 23.

21 ZUMA, N. (1998) "Tough anti-tobacco legislation moves forward in South Africa", The Lancet, November, 14: 1609.

22 ZINHUA NEWS AGENCY. (2001) "South Africa sets new deadline for implementation of smoking law", May, 1. 